Chirurgia (2018) 113: 291-299

No. 3, May - June

Copyright $@$ Celsius

http://dx.doi.org/10.21614/chirurgia.113.3.291

\title{
Managing Infected Pancreatic Necrosis
}

\author{
John-Edwin Thomson ${ }^{1,2}$, Sven M Van Dijk ${ }^{2,3}$, Martin Brand ${ }^{4}$, Hjalmar C Van Santvoort ${ }^{3,5}$, \\ Marc G Besselink ${ }^{2}$ for the Dutch Pancreatitis Study Group
}

'Department of Surgery, University of the Witwatersrand, Johannesburg, South Africa

2Department of Surgery, Amsterdam Gastroenterology and Metabolism, Amsterdam UMC, University of Amsterdam, the Netherlands

${ }^{3}$ Department of Surgery, St. Antonius Hospital, Nieuwegein, the Netherlands

${ }^{4}$ Department of Surgery, University of Pretoria and School of Physiology, University of the Witwatersrand, South Africa

${ }^{5}$ Department of Surgery, University Medical Center Utrecht Cancer Center, Utrecht University, the Netherlands

Corresponding author:

Professor Marc G Besselink

Amsterdam UMC

University of Amsterdam, the Netherlands

E-mail:m.g.besselink@amc.uva.nl

\section{Rezumat}

\section{Managementul necrozei pancreatice infectate}

Managementul necrozei pancreatice infectate a început cu necrozectomia deschisă precoce, asociată cu o mortalitate semnificativă. În ultimii ani, a avut loc o transformare bazată pe dovezi înspre abordarea progresivă constând în drenajul percutan urmat de necrozectomia minim invazivă dacă este necesar. Mai recent, abordarea endoscopică progresivă a câştigat popularitate. Aceast articol evaluează diagnosticul, prevenirea şi tratamentul necrozei pancreatice infectate.

Punctele cheie în gestionarea necrozei pancreatice infectate:

- abordarea echipei multidisciplinare în centrele de nivel terțiar;

- nu există indicație pentru administrarea profilactică a antibioticelor sau a probioticelor;

- nutriția enterală nazogastrică indicată după 72 de ore, dacă alimentarea pe cale orală este insuficientă;

- intervenție doar în necroza infectată;

- întârzierea intervenției până la necroza cu perete format (walled-off necrosis);

- abordarea progresivă a drenajului endoscopic percutan urmată de necrosectomie minim invazivă, dacă este necesar;

- abordările endoscopice sunt preferabile acolo unde este posibil.

Cuvinte cheie: pancreatită, necroză pancreatică infectată, necrozectomie 


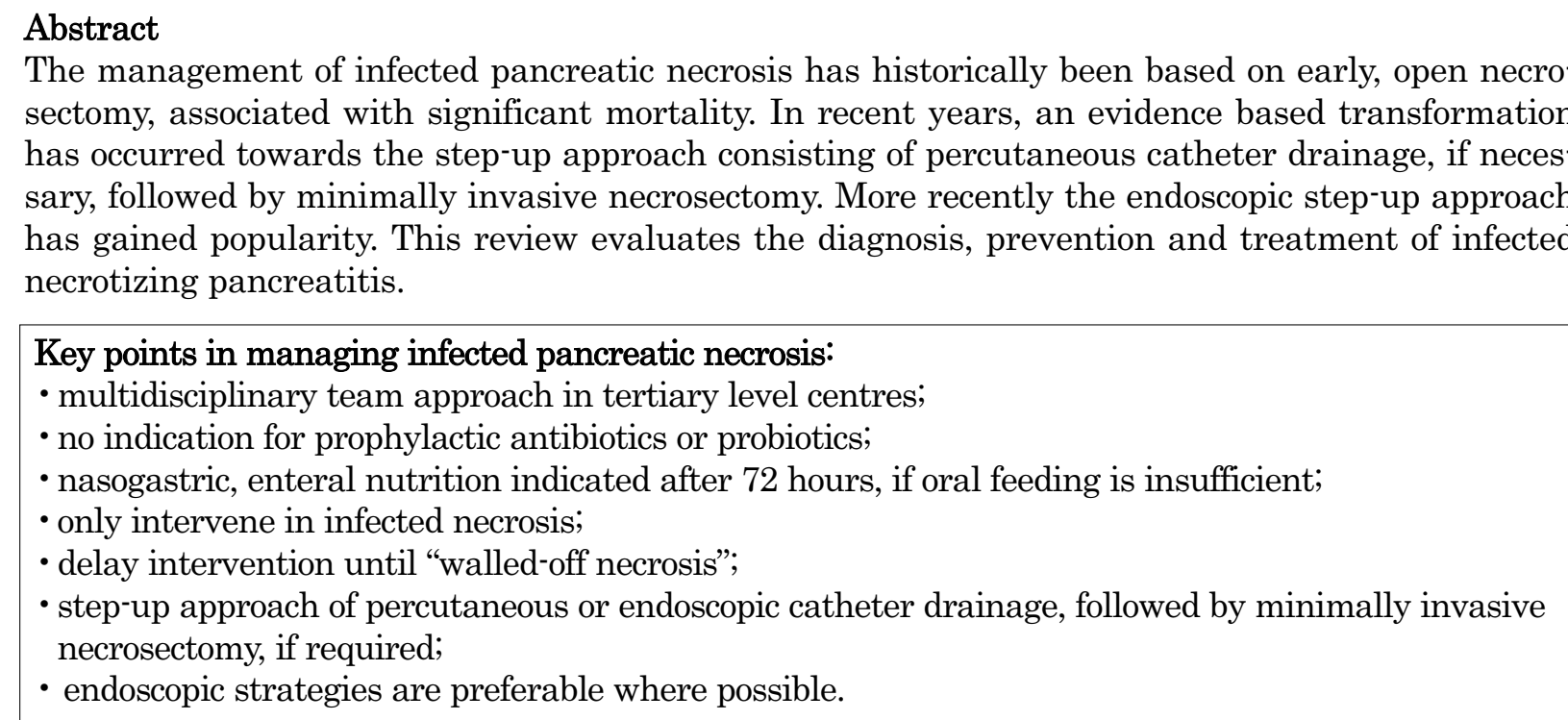

Key words: pancreatitis, infected pancreatic necrosis, necrosectomy

\section{Introduction}

Acute pancreatitis (AP) is an inflammatory process of the pancreas involving a varied local and systemic inflammatory response. The rising incidence of AP in both the United States and Europe has placed an increasing burden on healthcare services $(1,2)$. The majority of cases of AP are mild and thus self-limiting, with an associated mortality rate below $1 \%(3)$. The remaining $20 \%$ of patients will develop severe acute pancreatitis (SAP), with an associated mortality rate of $10-40 \%(3)$.

The predominant aetiological factors of AP are gallstones and/or biliary sludge and alcohol. Irrespective of the aetiology of AP, intra-pancreatic activation of digestive enzymes, coupled with persistently elevated cytosolic calcium, triggers activation of trypsinogen $(4,5)$ resulting in pancreatic autodigestion. Alterations in the microcirculation of the pancreas as a result of hypovolaemia, increased capillary permeability, possible localised vasoconstriction as well as hypercoagulability all contribute to pancreatic ischaemia (6). In combination with the release of various inflammatory mediators, cellular apoptosis and necrosis, either peripancreatic or pancreatic necrosis or both can result. Necrosis is directly related to disease severity and secondary infection of this necrosis is responsible for between $66-80 \%$ of late mortality in patients with SAP (7-9). Thus, the formation of necrosis and subsequent infection thereof carries significant prognostic implications.

Inhibition of the cascade of events that lead to development and progression of AP has been subject of much investigation. Strategies to prevent the formation of pancreatic necrosis would be clearly beneficial in AP. To date, therapy remains largely supportive in the early phase of AP. Adequate fluid resuscitation is essential to improve patient outcomes (10), but does not prevent the formation of pancreatic necrosis per se (11). Furthermore, modulation of pro-inflammatory, anti-inflammatory and/or cellular responses have shown promise in experimental models, but were not beneficial in the clinical setting (5). Thus, efforts need to be concentrated on optimal prevention of infected pancreatic necrosis as well as 
improving management strategies. This review provides a summary on the prevention, diagnosis and treatment strategies of patients with infected pancreatic necrosis.

\section{General Approach}

It is generally understood that a bimodal pattern of organ failure occurs in SAP. Within the first week, multi-organ failure is a result of the systemic inflammatory response syndrome (SIRS). Thereafter, organ failure usually occurs secondary to septic complications arising from infected pancreatic necrosis. In addition, the recognition that pancreatic and peripancreatic necrosis evolves over time either undergoing liquefaction or infection or even complete resolution underpins further management. Based on this understanding and the advancement of treatment strategies, a multidisciplinary approach to the management of SAP has become critical. Interaction between intensivists, surgeons, endoscopists, interventional radiologists as well as allied healthcare professionals is vital in the successful management of these complex patients. Considering the complexity of patients with SAP as well as the various disciplines required in their management strategies, such patients should be treated in tertiary level institutions with experience in managing SAP.

\section{Prevention of Infection of Pancreatic Necrosis}

Increased intestinal permeability and bacterial translocation that occurs in AP is thought to be fundamental to the formation of infected (peri-)pancreatic necrosis. Intestinal permeability has been shown to increase early in SAP (13) which is further compromised by impaired splanchnic perfusion (14), all leading to the development of bacterial translocation (15). Bacteraemia has been identified as an independent risk factor for both the development of infection in (peri-)pancreatic necrosis as well as death (16). A hypo-inflammatory state, driven by the compensatory anti-inflammatory response syndrome (CARS), during the late phase of SAP has been hypothesised to result in immune paresis (17). A collection with (peri-)pancreatic necrosis coupled with immune paresis and bacteraemia therefore seems a recipe for sepsis. Thus, prevention of bacterial translocation by maintaining intestinal barrier function (18) may offer a chance to reduce the development of infected (peri-)pancreatic necrosis and sub-sequent morbidity and mortality.

\section{Antibiotics}

The impact of prophylactic antibiotics in patients with necrotizing pancreatitis was assessed by several double-blind randomised control trials (RCTs), which failed to show a benefit (19-21). A number of meta-analyses have confirmed these findings (22-24). Antibiotic therapy should only be considered as treatment in patients with necrotizing pancreatitis in whom there is strong clinical suspicion of infected necrosis or proven sepsis.

\section{Probiotics}

Probiotics are non-pathological bacteria which may exert a number of beneficial effects on a host's intestinal microbiome. By reducing the quantity of pathogenic bacteria within the gastrointestinal tract, promoting restoration of intestinal permeability well as immune modulation within the small bowel (25), probiotic therapy has shown much promise in surgical patients. Initially, two small RCTs in patients SAP demonstrated encouraging results $(26,27)$. A subsequent multicentre, double-blind, placebo controlled trial, from the Netherlands however, refuted the early findings. This trial of 296 patients unexpectedly resulted in increased mortality rates as a result of bowel ischaemia in the probiotic group compared to the placebo group (28). A subsequent study further supported the deleterious effects of probiotics in patients with organ failure, demonstrating worsening enterocyte function and increased bacterial translocation (18). As a result the administration of probiotics in SAP is not recommended. 


\section{Enteral Nutrition}

Evidence in recent years has established that enteral nutrition in SAP is not merely a method to deliver calories to the patient, but a therapeutic strategy. Enteral nutrition when compared to parenteral nutrition has demonstrated significantly lower rates of (peri-)pancreatic infection, general septic complications as well as reduced mortality (29-31). By promoting intestinal motility as well as enhancing luminal nutrition and increasing splanchnic blood flow, enteral nutrition reduces bacterial overgrowth and thus bacterial translocation $(32,33)$. Thus, enteral nutrition is superior to parental nutrition and has replaced it in SAP.

With the significance of enteral nutrition established, research intensified on the timing of initiation of enteral nutrition. Early data based on non-randomized studies suggested a benefit for initiating enteral feeding within 48 hours of admission $(34,35)$. Subsequently two RCTs have investigated early enteral nutrition ( $<24$ hours from admission) with on-demand enteric feeding (36) and no nutritional support (37), concluding that early enteral feeding is not beneficial. Furthermore, nasogastric feeding has been demonstrated to be safe and noninferior when compared to nasojejunal feeding (38-41). Consequently, it is recommended that nasogastric enteral nutrition can be initiated in SAP patient that are not consuming adequate oral caloric intake after 72 hours of admission.

\section{Diagnosis of Infection}

The definitive detection of infected necrosis is paramount as it necessitates different management than sterile necrosis (42). Infection can be diagnosed either by;

1. Clinical suspicion;

2. Percutaneous fine-needle aspiration (FNA) of the necrotic collection with a positive gram stain or culture;

3. Radiologically demonstrated gas 'bubbles' within (peri-)pancreatic necrosis.

Clinical suspicion of infected necrosis is primarily driven by fever, worsening septic markers, positive blood cultures and/or (new- onset) organ failure. During the early phase of pancreatitis these parameters are known to be inaccurate (43) thus intervention based on a high clinical suspicion of infected (peri-)pancreatic necrosis is ideally delayed until 4 weeks after onset of disease once "walled off necrosis' has occurred (10). The utilization of FNA aspiration and culture has become less favourable due to a $20-25 \%$ false negative rate, potentially as a result of the timing of the FNA as well as prior antibiotic usage (14). International experts agree that currently there is no consensus on the role of FNA and therefore it is not used routinely (44). For example, a stable patient with a positive FNA can potentially be treated with antibiotics alone and conversely patients with a high level of clinical suspicion and/or organ failure with a negative FNA will progress to further surgical intervention. In patients that have persistently high inflammatory markers after SIRS as well as ongoing organ dysfunction and no radiological indication of (peri-)pancreatic sepsis, FNA may be beneficial to determine whether further surgical intervention is required $(42,45)$. Bacteraemia has been shown to precede and increase the risk of developing infected (peri-) pancreatic necrosis (16) and therefore should be a strong consideration of the presence of infected (peri-)pancreatic necrosis. However, extrapancreatic sepsis such as pneumonia, venous catheters sepsis and urinary tract infections occur in up to $33 \%$ of patients with SAP (46) and therefore isolated bacteraemia should alert treating physicians to this possibility. Cross sectional imaging such as CT or MRI occasionally reveals gas within the (peri-)pancreatic necrosis (Fig. 1), which is diagnostic of infection (3). Gas is present in approximately $42 \%$ of patients with infected necrosis (45).

\section{Timing of Intervention}

In patients with infected (peri-)pancreatic necrosis, the timing of intervention is not well established. There are numerous reasons for delaying surgical intervention. Firstly, encapsulation of the collections evolves over time 


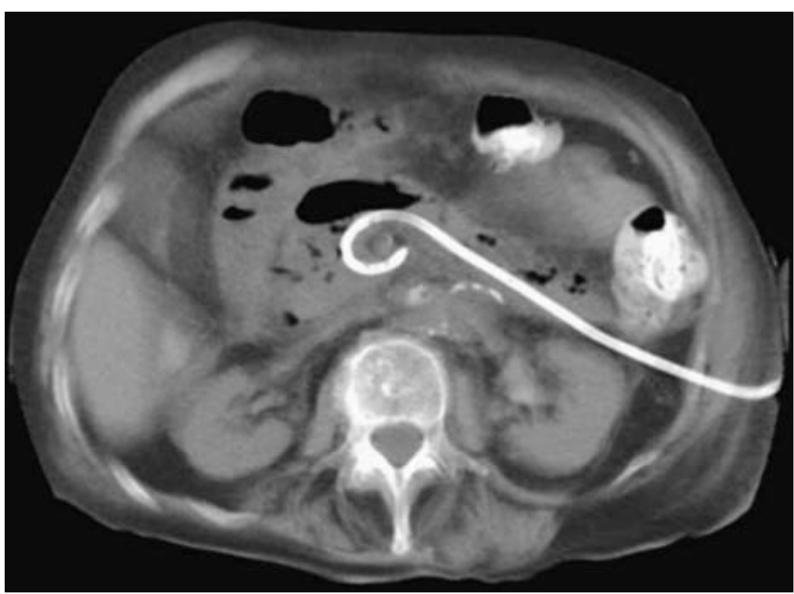

Figure 1. Infected (peri-)pancreatic necrosis with percutaneous catheter drain in situ via the left retroperitoneum thus avoiding the peritoneal cavity (12)

towards walled off necrosis (WON) as the necrosis liquefies, facilitating the procedures. Current guidelines recommend delaying intervention until around 3-4 weeks to allow this process to occur $(3,10,47)$. Secondly, extrapolated data from patients undergoing open necrosectomies demonstrated poorer outcomes in patients that had early necrosectomies (10). Finally, the risk of bowel perforation and bleeding during necrosectomy decreases as the collection matures towards WON.

It is recognised, however, that in certain patients delaying drainage for 4 weeks is not always possible due to deteriorating sepsis. It is believed that by releasing the pressure of the infected (peri-)pancreatic fluid systemic sepsis is halted. This in turn allows for further antibiotic therapy to take place and continued maturation of the WON (48). In such cases, percutaneous drainage should be performed and if required, the necrosectomy delayed. The POINTER trial (ISCRTN33682933), a multicentre RCT, is currently recruiting patients to compare the outcomes of immediate $(<24 \mathrm{hrs})$ versus delayed drainage after diagnosing infected (peri-)pancreatic necrosis. The outcome of this trial will provide guidance into the timing of intervention and is eagerly awaited.

\section{Invasive Intervention}

Acute necrotic collections (ANC) and WON carry a $32 \%$ risk of becoming infected (49), which may necessitate invasive intervention. Despite some publications reporting successfully treating infected (peri-)pancreatic necrosis with antibiotic therapy alone, most patients will progress to an invasive intervention (50-52). Sterile necrosis should be treated conservatively (49). Symptomatic sterile necrosis is somewhat more of a difficult issue. Interventions in such patients should not be taken lightly, as the risk of introducing sepsis into the (peri-)pancreatic necrosis is very high. Infected (peri-)pancreatic necrosis was historically treated with early laparotomy and debridement of the necrotic material.This approach was however associated with significant morbidity, mortality as well as long term pancreatic insufficiency (52). A landmark publication in 2010 revolutionized the surgical invention of infected (peri-)pancreatic necrosis, demonstrating the superiority of the minimally invasive step-up approach (52). As a result, initial percutaneous catheter drainage, followed by, if necessary, necrosectomy, the so called 'step-up approach', has become the standard of care. Catheter drainage (Fig. 1) will successfully treat infected (peri-)pancreatic necrosis in $35-70 \%$ of cases (52-55), without the need for an additional necrosectomy.

The approach to necrosectomies has also shifted to minimally invasive techniques. Minimally invasive retroperitoneal, endoscopic and laparoscopic necrosectomies have all been performed. Video-assisted retroperitoneal debridement (VARD) is a relatively straightforward strategy for patients in whom left or right sided retroperitoneal collections with infected necrosis are drained (12). Using a small (i.e. $5 \mathrm{~cm}$ ) incision, with a zero-degree camera and long graspers, a minimally invasive necrosectomy is safely performed (Fig. 2). A recent analysis of 1980 patients favoured endoscopic and minimally invasive surgical necrosectomies in very high risk patients, demonstrating a lower risk of mortality when compared to patients that underwent open necrosectomies (57).

A pilot RCT comparing endoscopic transluminal necrosectomy with minimally invasive necrosectomies concluded that the endoscopic 


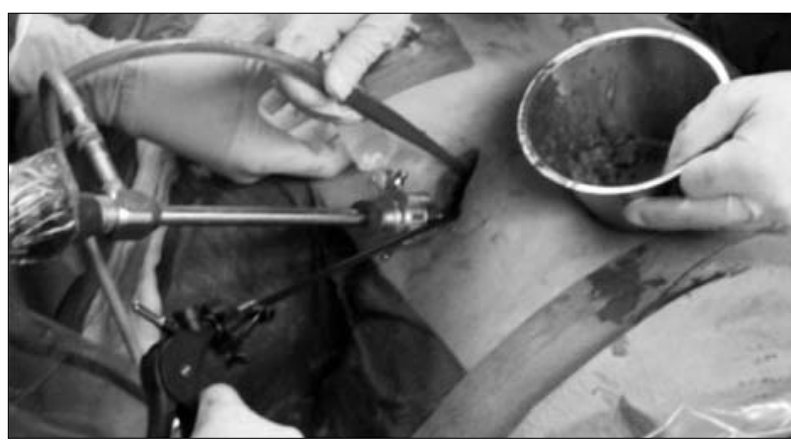

Figure 2. Video-assisted retroperitoneal debridement (VARD) (56)

approach reduces the pro-inflammatory response, major complications, pancreatic fistulae and death (58). The more recent, larger TENSION RCT compared endoscopic transluminal drainage with endoscopic necrosectomy (if necessary) with percutaneous catheter drainage followed by VARD (if required) (53). The endoscopic step-up approach failed to demonstrate superiority when compared to the surgical step-up approach with regard to reducing major complications or death. However, the formation of pancreatic fistulae as well as duration of hospitalization were less in the endoscopy group.

Many variables have been introduced in the era of managing infected (peri-)pancreatic necrosis through minimally invasive techniques that require further investigation. The initial sizes of drains and stents, the number as well as the role/timing of upsizing these drains or stents, the ideal types of drains and stents as well as the route, method and type of lavage all still need to be established. Additionally, the combination of both endoscopic and minimally invasive techniques are possible, but the benefit thereof is untested. Currently the evidence is clearly in favour of a step-up approach in the management of infected (peri-)pancreatic necrosis with a preference to minimally invasive necrosectomies. Furthermore, initial data indicates that the endoscopic route may potentially be more beneficial when compared to the percutaneous minimally invasive route.

\section{Special Considerations}

\section{Indication for ERCP in Severe Acute Biliary Pancreatitis}

The indication and timing of endoscopic retrograde cholangiopancreatography (ERCP) with sphincterotomy during acute biliary pancreatitis $(\mathrm{ABP})$ have long been subject to investigation. ERCP's are associated with complications in $7-10 \%$ of cases and have a mortality of $0.2-2.2 \%$ (59). Furthermore, post ERCP-pancreatitis can occur in patients with active pancreatitis, independent of aetiology, exacerbating the course of pancreatitis. Therefore, performing an ERCP in a patient with $\mathrm{ABP}$ with a so-called 'primed' pancreas has the potential for significant morbidity and/or mortality, thus should only be performed where indicated.

There is strong evidence that early $(<24$ hours) ERCP should be performed in patients with concomitant cholangitis (60). Some authors have advocated early ERCP intervention in all patients with (predicted) severe biliary pancreatitis $(61,62)$, however this has not become standard of care $(10,47)$. The multicentre APEC trial is currently studying the impact of routine early ( $<24$ hours) ERCP in predicted severe biliary pancreatitis (63). There is consensus that patients with mild and moderate AP do not require early ERCP (62), as potential benefits do not outweigh the procedural risks. There is no evidence that early ERCP prevents the development of (peri)pancreatitis necrosis. Delayed ERCP's in ABP should be performed for persistent choledocholithiasis.

\section{Timing of Cholecystectomy in Biliary Pancreatitis}

A recent multicentre trial has clearly confirmed that in patients with mild biliary pancreatitis, cholecystectomy should be performed during index admission (64). Rates of readmission for recurrent biliary events can be reduced from $17 \%$ to $5 \%$ if cholecystectomy is performed in the same admission as opposed to an interval 
cholecystectomy. The timing of a cholecystectomy in severe ABP is much more complex. Cholecystectomy in severe $\mathrm{ABP}$ should be delayed until local complications have resolved or until 6 weeks after discharge (65) to reduce the risk of infecting sterile collections. A sphincterotomy can further reduce the risk of recurrent pancreatitis (66) but should only be performed as a temporising measure in patients that are unfit for general anaesthesia and hence definitive cholecystectomy. Should intraabdominal surgery be performed during the initial hospitalization for a related complication, a cholecystectomy should probably be performed if safe and feasible.

\section{Irrigation and Removal of Drains}

No evidence exists guiding the nature of irrigation and the withdrawal thereof. Common practise is to start with higher amounts of normal saline and to systematically decrease the volume and frequency as the effluent becomes less particulate and clearer until no further lavage is required. Continued withdrawal of lavage should be performed in conjunction with persistently decreasing systemic markers and reinstituted if sepsis worsens. Drains should only be removed if effluent is clear and with amylase levels below three times the upper limit of normal serum levels.

\section{Long Term Management}

As a result of extensive pancreatic tissue loss due to the necrotic process, endocrine and exocrine dysfunction has been reported in 19\%$80 \%$ of patients (67). The risk of developing chronic pancreatitis ranges from $8 \%$ to $16 \%$ $(68,69)$ after necrotizing pancreatitis. In addition, there is a (weak) association between acute pancreatitis and the development of pancreatic adenocarcinoma. A recent review concluded that $11 \%$ of patients 40 years and older who developed pancreatic adenocarcinoma had had acute pancreatitis within the preceding two years (70). For all of the above reasons, patients who have had necrotising pancreatitis without a clear cause should be followed up at least once with an abdominal CT scan.

\section{Conclusion}

The management of infected pancreatic necrosis has dramatically changed over the past decade. A delayed, step-up approach with minimally invasive interventions is now the preferred approach for infected pancreatic necrosis.

\section{Acknowledgements}

South African Society of Endoscopic Surgeons for the financial travel grant to the Amsterdam UMC, location Academic Medical Center.

\section{Authors' Contributions}

Conception or design of the work: JT, MGB; Drafting the article: JT; Critical revision of the article: MB, SMvD, HCvS,MGB; Final approval of the version to be published: JT, MGB.

Conflict of Interest: none declared.

\section{References}

1. Yadav D, Lowenfels $A B$. The Epidemiology of Pancreatitis and Pancreatic Cancer. 2014;144(6):1252-61.

2. Roberts SE, Morrison-Rees S, John A, Williams JG, Brown TH, Samuel DG. The incidence and aetiology of acute pancreatitis across Europe. Pancreatology. 2017;17(2):155-65.

3. Banks PA, Bollen TL, Dervenis C, Gooszen HG, Johnson CD, Sarr MG, et al. Classification of acute pancreatitis--2012: revision of the Atlanta classification and definitions by international consensus. Gut. 2013;62(1):102-11.

4. Sutton R, Criddle D, Raraty MGT, Tepikin A, Neoptolemos JP, Petersen $\mathrm{OH}$. Signal transduction, calcium and acute pancreatitis. Pancreatology. 2003;3(6):497-505.

5. Akinosoglou K, Gogos C. Immune-modulating therapy in acute pancreatitis: fact or fiction. World J Gastroenterol. 2014;20(41): 15200-15.

6. Gardner TB, Vege SS, Pearson RK, Chari ST. Fluid Resuscitation in Acute Pancreatitis. Clin Gastroenterol Hepatol. 2008;6(10):1070-6.

7. Büchler MW, Gloor B, Müller CA, Friess H, Seiler CA, Uhl W. Acute necrotizing pancreatitis: treatment strategy according to the status of infection. Ann Surg. 2000;232(5):619-26.

8. Runkel NS, Rodriguez LF, Moody FG. Mechanisms of sepsis in acute pancreatitis in opossums. Am J Surg. 1995;169(2):227-32.

9. Renner IG, Savage WT, Pantoja JL, Renner VJ. Death due to acute pancreatitis. A retrospective analysis of 405 autopsy cases. Dig Dis Sci. 1985;30(10):1005-18.

10. Group W, Apa IAP, Pancreatitis A. IAP/APA evidence-based guidelines for the management of acute pancreatitis. Pancreatology. 2013;13(4):e1-15. 
11. Brown A, Baillargeon J-D, Hughes MD, Banks P a. Can fluid resuscitation prevent pancreatic necrosis in severe acute pancreatitis? Pancreatology. 2002;2(2):104-7.

12. van Santvoort HC, Besselink MGH, Horvath KD, Sinanan MN Bollen TL, van Ramshorst B, et al. Videoscopic assisted retroperitoneal debridement in infected necrotizing pancreatitis. Hpb. 2007; 9(2):156-9

13. Rahman SH, Ammori BJ, Holmfield J, Larvin M, McMahon MJ, Sarr MG, et al. Intestinal hypoperfusion contributes to gut barrier failure in severe acute pancreatitis. J Gastrointest Surg. 2003; 7(1):26-36.

14. Inoue K, Hirota M, Kimura Y, Kuwata K, Ohmuraya M, Ogawa M. Further evidence for endothelin as an important mediator of pancreatic and intestinal ischemia in severe acute pancreatitis. Pancreas. 2003;26(3):218-23.

15. Bakker OJ, van Santvoort HC, Besselink MGH, van der Harst E, Hofker HS, Gooszen HG. Prevention, detection, and management of infected necrosis in severe acute pancreatitis. Curr Gastroenterol Rep. 2009:11:104-10.

16. Besselink MG, Van Santvoort HC, Boermeester MA, Nieuweohuijs VB, Van Goor H, Dejong CHC, et al. Timing and impact of infections in acute pancreatitis. Br J Surg. 2009;96(3):267-73.

17. Dambrauskas Z, Giese N, Gulbinas A, Giese T, Berberat PO, Pundzius J, et al. Different profiles of cytokine expression during mild and severe acute pancreatitis. World J Gastroenterol. 2010; 16(15):1845-53.

18. Besselink MG, van Santvoort HC, Renooij W, de Smet MB, Boermeester MA, Fischer K, et al. Intestinal Barrier Dysfunction in a Randomized Trial of a Specific Probiotic Composition in Acute Pancreatitis. Ann Surg. 2009;250(5):712-9.

19. Isenmann R, Rünzi M, Kron M, Kahl S, Kraus D, Jung N, et al. Prophylactic Antibiotic Treatment in Patients with Predicted Severe Acute Pancreatitis: A Placebo-Controlled, Double-Blind Trial Gastroenterology. 2004;126(4):997-1004.

20. Dellinger EP, Tellado JM, Soto NE, Ashley SW, Barie PS, Dugernier T, et al. Early Antibiotic Treatment for Severe Acute Necrotizing Pancreatitis. Ann Surg. 2007;245(5):674-83.

21. García-Barrasa A, Borobia FG, Pallares $R$, Jorba $R$, Poves I, Busquets $\mathrm{J}$, et al. A double-blind, placebo-controlled trial of ciprofloxacin prophylaxis in patients with acute necrotizing pancreatitis. J Gastrointest Surg. 2009;13(4):768-74.

22. Villatoro $E$, Mulla M, Larvin M. Antibiotic therapy for prophylaxis against infection of pancreatic necrosis in acute pancreatitis (Review). Cochrane database Syst Rev. 2010;(5):1-52.

23. Wittau M, Mayer B, Scheele J, Henne-Bruns D, Dellinger EP, Isenmann $R$. Systematic review and meta-analysis of antibiotic prophylaxis in severe acute pancreatitis. Scand J Gastroenterol. 2011;46(3):261-70.

24. Lim CLL, Lee W, Liew YX, Tang SSL, Chlebicki MP, Kwa ALH. Role of Antibiotic Prophylaxis in Necrotizing Pancreatitis: A MetaAnalysis. J Gastrointest Surg. 2015;19(3):480-91.

25. Bengmark S. Ecological control of the gastrointestinal tract. The role of probiotic flora. Gut. 1998;42(1):2-7

26. Oláh A, Belágyi T, Issekutz A, Gamal ME, Bengmark S. Randomized clinical trial of specific lactobacillus and fibre supplement to early enteral nutrition in patients with acute pancreatitis. Br J Surg. 2002;89(9):1103-7.

27. Oláh A, Belágyi T, Pótó L, Romics L, Bengmark S. Synbiotic control of inflammation and infection in severe acute pancreatitis: a prospective randomized, double blind study. Hepatogastroenterology. 2007; 54(74):590-4.

28. Besselink MG, van Santvoort HC, Buskens E, Boermeester MA, van Goor H, Timmerman HM, et al. Probiotic prophylaxis in predicted severe acute pancreatitis: a randomised, double-blind, placebocontrolled trial. Lancet. 2008;371(9613):651-9.

29. Petrov M, van Santvoort H, Besselink M, van der Heijden G, Windsor J, Gooszen H. Enteral Nutrition and the Risk of Mortality and Infectious Complications in Patients With Severe Acute Pancreatitis. 2008;143(11):1111-7.

30. Zh A, Mf T, La A. Enteral versus parenteral nutrition for acute pancreatitis (Review). Cochrane database Syst Rev. 2010;(1)

31. Marik PE, Zaloga GP. Early enteral nutrition in acutely ill patients: a systematic review. Crit Care Med. 2001;29(12):2264-70.

32. McClave SA, Heyland DK. The physiologic response and associated clinical benefits from provision of early enteral nutrition. Nutr Clin Pract. 2009;24(3):305-15.

33. Marik PE. What is the best way to feed patients with pancreatitis? Curr Opin Crit Care. 2009;15(2):131-8.

34. Petrov MS, Pylypchuk RD, Uchugina AF. A systematic review on the timing of artificial nutrition in acute pancreatitis. Br J Nutr. 2009; 101(6):787

35. Li J-Y, Yu T, Chen G-C, Yuan Y-H, Zhong W, Zhao L-N, et al. Enteral nutrition within 48 hours of admission improves clinical outcomes of acute pancreatitis by reducing complications: a meta-analysis. Rakonczay Z, editor. PLoS One. 2013;8(6):e64926.

36. Bakker OJ, van Brunschot S, van Santvoort HC, Besselink MG, Bollen TL, Boermeester MA, et al. Early versus on-demand nasoenteric tube feeding in acute pancreatitis. N Engl J Med. 2014; 371(21):1983-93

37. Stimac D, Poropat G, Hauser G, Licul V, Franjic N, Valkovic Zujic P, et al. Early nasojejunal tube feeding versus nil-by-mouth in acute pancreatitis: A randomized clinical trial. Pancreatology. 2016; 16(4):523-8

38. Eatock FC, Chong P, Menezes N, Murray L, McKay CJ, Carter CR, et al. A Randomized Study of Early Nasogastric versus Nasojejunal Feeding in Severe Acute Pancreatitis. Am J Gastroenterol. 2005; 100(2):432-9.

39. Kumar A, Singh N, Prakash S, Saraya A, Joshi YK. Early enteral nutrition in severe acute pancreatitis: a prospective randomized controlled trial comparing nasojejunal and nasogastric routes. J Clin Gastroenterol. 2006;40(5):431-4.

40. Singh N, Sharma B, Sharma M, Sachdev V, Bhardwaj P, Mani K, et al. Evaluation of Early Enteral Feeding Through Nasogastric and Nasojejunal Tube in Severe Acute Pancreatitis. Pancreas. 2012; 41(1):153-9.

41. Chang Y, Fu H, Xiao Y, Liu J. Nasogastric or nasojejunal feeding in predicted severe acute pancreatitis: a meta-analysis. Crit Care. 2013;17(3):R118.

42. Da Costa DW, Boerma D, Van Santvoort HC, Horvath KD, Werner J, Carter CR, et al. Staged multidisciplinary step-up management for necrotizing pancreatitis. Br J Surg. 2014;101(1):65-79.

43. Meynaar IA, Droog W, Batstra M, Vreede R, Herbrink P. In Critically III Patients, Serum Procalcitonin Is More Useful in Differentiating between Sepsis and SIRS than CRP, II-6, or LBP. Crit Care Res Pract. 2011;2011:594645

44. van Grinsven J, van Brunschot S, Fockens P, van Grinsven J, Bakker OJ, van Santvoort HC, et al. Diagnostic strategy and timing of intervention in infected necrotizing pancreatitis: an international expert survey and case vignette study. Hpb. 2016;18(1):49-56.

45. Van Baal MC, Bollen TL, Bakker OJ, Van Goor H, Boermeester MA, Dejong $\mathrm{CH}$, et al. The role of routine fine-needle aspiration in the diagnosis of infected necrotizing pancreatitis. Surg (United States). 2014;155(3):442-8.

46. Koutroumpakis E, Slivka A, Furlan A, Dasyam AK, Dudekula A, Greer JB, et al. Management and outcomes of acute pancreatitis patients over the last decade: A US tertiary-center experience. Pancreatology. 2017;17(1):32-40.

47. Tenner S, Baillie J, Dewitt J, Vege SS. American College of Gastroenterology Guideline: Management of Acute Pancreatitis. Am J Gastroenterol. 2013;(December 2012):1-16.

48. van Grinsven J, van Santvoort HC, Boermeester MA, Dejong $\mathrm{CH}$, van Eijck $\mathrm{CH}$, Fockens $\mathrm{P}$, et al. Timing of catheter drainage in infected necrotizing pancreatitis. Nat Rev Gastroenterol Hepatol. 2016;13(5): 306-12. 
49. Van Santvoort HC, Bakker OJ, Bollen TL, Besselink MG, Ahmed Ali $U$, Schrijver AM, et al. A conservative and minimally invasive approach to necrotizing pancreatitis improves outcome. Gastroenterology. 2011;141(4):1254-63.

50. Adler DG, Chari ST, Dahl TJ, Farnell MB, Pearson RK. Conservative management of infected necrosis complicating severe acute pancreatitis. Am J Gastroenterol. 2003;98(1):98-103.

51. Runzi M, Niebel W, Goebell H, Gerken G, Layer P. Severe acute pancreatitis: nonsurgical treatment of infected necroses. Pancreas. 2005;30(3):195-9.

52. van Santvoort HC, Besselink MG, Bakker OJ, Hofker HS, Boermeester MA, Dejong $\mathrm{CH}$, et al. A step-up approach or open necrosectomy for necrotizing pancreatitis. N Engl J Med. 2010; 362(16):1491-502.

53. van Brunschot S, van Grinsven J, van Santvoort HC, Bakker OJ, Besselink MG, Boermeester MA, et al. Endoscopic or surgical stepup approach for infected necrotising pancreatitis : a multicentre randomised trial. Lancet. 2017;6736(17):1-8.

54. Van Baal MC, Van Santvoort HC, Bollen TL, Bakker OJ, Besselink MG, Gooszen HG. Systematic review of percutaneous catheter drainage as primary treatment for necrotizing pancreatitis. $\mathrm{Br} \mathrm{J}$ Surg. 2011;98(1):18-27.

55. van Grinsven J, Timmerman P, van Lienden KP, Haveman JW, Boerma D, van Eijck CHJ, et al. Proactive Versus Standard Percutaneous Catheter Drainage for Infected Necrotizing Pancreatitis. Pancreas. 2017;46(4):518-23.

56. Bollen T, Marieke H, Robin S. Pancreas - Acute Pancreatitis 2.0 [Internet]. 2015 [cited 2017 Nov 26]. Available from: http://www.radiologyassistant.nl/en/p550455dae5806/pancreas-acute-pancreatitis-20.html

57. van Brunschot S, Hollemans RA, Bakker OJ, Besselink MG, Baron $\mathrm{TH}$, Beger $\mathrm{HG}$, et al. Minimally invasive and endoscopic versus open necrosectomy for necrotising pancreatitis: a pooled analysis of individual data for 1980 patients. Gut. 2017;0:1-10

58. Bakker OJ, van Santvoort HC, Brunschot S Van, Geskus RB, Besselink MG, Bollen TL, et al. Endoscopic Transgastric vs Surgical Necrosectomy for Infected Necrotizing Pancreatitis. JAMA. 2012; 307(10):1053-61.

59. Anderloni A, Repici A. Role and timing of endoscopy in acute biliary pancreatitis. World J Gastroenterol. 2015;21(40):11205-8.

60 . Tse F, Yuan Y. Early routine endoscopic retrograde cholangiopancreatography strategy versus early conservative management strategy in acute gallstone pancreatitis. Cochrane Database Syst Rev. 2012;5(5):CD009779.

61. Burstow MJ, Yunus RM, Hossain MB, Khan S, Memon B, Memon MA. Meta-Analysis of Early Endoscopic Retrograde Cholangiopancreatography (ERCP) \pm Endoscopic Sphincterotomy (ES) Versus Conservative Management for Gallstone Pancreatitis (GSP). Surg Laparosc Endosc Percutaneous Tech. 2015;25(3):185-203.

62. van Santvoort HC, Besselink MG, de Vries AC, Boermeester MA, Fischer K, Bollen TL, et al. Early Endoscopic Retrograde Cholangiopancreatography in Predicted Severe Acute Biliary Pancreatitis. Ann Surg. 2009;250(1):68-75.

63. Schepers NJ, Bakker OJ, Besselink MGH, Bollen TL, Dijkgraaf MGW, van Eijck $\mathrm{CHJ}$, et al. Early biliary decompression versus conservative treatment in acute biliary pancreatitis (APEC trial): study protocol for a randomized controlled trial. Trials. 2016;17(1):5

64. Da Costa DW, Bouwense SA, Schepers NJ, Besselink MG, Van Santvoort $\mathrm{HC}$, Van Brunschot S, et al. Same-admission versus interval cholecystectomy for mild gallstone pancreatitis (PONCHO): A multicentre randomised controlled trial. Lancet. 2015; 386(10000):1261-8.

65. Nealon WH, Bawduniak J, Walser EM. Appropriate Timing of Cholecystectomy in Patients Who Present With Moderate to Severe Gallstone-Associated Acute Pancreatitis With Peripancreatic Fluid Collections. Ann Surg. 2004;239(6):741-51.

66. Heider TR, Brown A, Grimm IS, Behrns KE. Endoscopic sphincterotomy permits interval laparoscopic cholecystectomy in patients with moderately severe gallstone pancreatitis. J Gastrointest Surg. 2006;10(1):1-5.

67. Van Dijk SM, Hallensleben NDL, Van Santvoort HC, Fockens P, Van Goor H, Bruno MJ, et al. Recent advances in clinical practice Acute pancreatitis: recent advances through randomised trials. Gut. 2017;0(10):1-9.

68. Ahmed Ali U, Issa Y, Hagenaars JC, Bakker OJ, van Goor H, Nieuwenhuijs VB, et al. Risk of Recurrent Pancreatitis and Progression to Chronic Pancreatitis After a First Episode of Acute Pancreatitis. Clin Gastroenterol Hepatol. 2016;14(5):738-46.

69. Lankisch PG, Breuer N, Bruns A, Weber-Dany B, Lowenfels $A B$, Maisonneuve P. Natural History of Acute Pancreatitis: A Long-Term Population-Based Study. Am J Gastroenterol. 2009;104(11): 2797-805.

70. Munigala S, Kanwal F, Xian H, Scherrer JF, Agarwal B. Increased risk of pancreatic adenocarcinoma after acute pancreatitis. Clin Gastroenterol Hepatol. 2014;12(7). 